\title{
MANAJEMEN GURU ERA OTONOMI DAERAH
}

\author{
Muhammad Faishal Haq, M.Pd.I \\ Dosen STAI Ma'had Aly Al-Hikam Malang \\ e-mail: faishalhaq9@gmail.com
}

\begin{abstract}
Abstrak
Guru adalah salah satu faktor yang sangat penting yang mempengaruhi kualitas pendidikan secara umum dan secara khusus prestasi peserta didik. Pendidikan yang berkualitas hanya akan dapat diwujudkan jika tersedia guru yang berkualitas. Untuk mewujudkan guru yang berkualitas diperlukan manajemen guru yang efektif mulai dari pengangkatan, penempatan, induksi, kesejahteraan, dan pengembangan profesi guru.

Metode analisis dilakukan dengan membandingkan manajemen guru yang telah dilakukan selama ini dengan manajemen guru yang ideal. Dengan demikian dapat diketahui perbedaannya yang selanjutnya diberikan saran-saran pemecahannya.

Kenyataannya manajemen guru di Indonesia dari waktukewaktu semakin tidak efektif. Manajemen guru banyak dipengaruhi oleh politik lokal dan sering dipolitisasi oleh penguasa. Manajemen guru belum dilaksanakan secara partisipatif, transparan, dan akuntabel. Oleh karena itu diperlukan perubahan yang mendasar dalam manajemen guru yang dimulai dari perubahan undang-undang dan peraturan pemerintah.

Kata kuci: manajemen guru, rekrutmen, induksi, kesejahteraan, dan pengembangan profesi.
\end{abstract}

\section{A. Pendahuluan}

Undang-Undang Nomor 14 Tahun 2005 tentang Guru dan Dosen dan Peraturan Pemerintah Nomor 74 Tahun 2008 tentang Guru menyebutkan bahwa guru adalah pendidik profesional dengan tugas utama mendidik, mengajar, membimbing, mengarahkan, melatih, menilai, dan mengevaluasi peserta didik pada pendidikan anak usia dini jalur pendidikan formal, pendidikan dasar, dan pendidikan menengah. 
Di dalam Kamus Besar Bahasa Indonesia (KBBI) diterangkan bahwa manajemen adalah penggunaan sumber daya secara efektif untuk mencapai sasaran. KBBI mendefinisikan reformasi sebagai perubahan secara drastis untuk perbaikan di bidang sosial, politik, ekonomi atau agama di suatu masyarakat atau negara. Sementara itu Kamus Webster mengartikan reformasi adalah membuat sesuatu lebih baik dengan menghentikan praktik-praktik yang tidak benar atau mengenalkan prosedur yang lebih baik.

Undang-Undang Nomor 32 Tahun 2004 tentang Pemerintahan Daerah menyebut "otonomi daerah adalah hak, wewenang, dan kewajiban daerah otonom untuk mengatur dan mengurus sendiri urusan pemerintahan dan kepentingan masyarakat setempat sesuai dengan peraturan perundang-undangan." Penjelasan tentang daerah otonom yang selanjutnya disebut daerah, adalah kesatuan masyarakat hukum yang mempunyai batas-batas wilayah yang berwenang mengatur dan mengurus urusan pemerintahan dan kepentingan masyarakat setempat menurut prakarsa sendiri berdasarkan aspirasi masyarakat dalam sistem Negara Kesatuan Republik Indonesia.

Dalam pembukaan Undang-Undang Dasar 1945 diisyaratkan akan visi pendidikan Indonesia yaitu mencerdaskan kehidupan bangsa. Bangsa yang cerdas adalah yang mampu menggunakan akal dan budinya secara bijaksana. Untuk mewujukan bangsa yang cerdas, maka guru berada di garda terdepan.

Di Indonesia posisi guru yang sangat strategis tersebut menjadikan jabatan guru amat terhormat sehingga mendapat gelar "pahlawan tanpa tanda jasa". Vietnam dan Jepang adalah contoh lain negara yang menghargai guru pada posisi terpenting. Vietnam memiliki moto "No teacher, no education! No education, no economic and social development!". Di Jepang, konon pertanyaan pertama kaisar setelah Herosima dan Nagasaki dibom tahun 1945 adalah berapa jumlah guru yang ada. Karena dengan guru, dapat membangun kembali bangsa yang kuat. Demikian pentingnya posisi guru di Jepang maka ada pepatah "She no on wa yama yori mo takai, umi yori mo fukai" artinya jasa guru lebih tinggi dari gunung yang tertinggi, lebih dalam dari laut yang terdalam. Begitu strategisnya peran guru sehingga mendapat tempat yang terbaik di masyarakat.

Guru adalah salah satu faktor yang sangat penting dalam mempengaruhi kualitas pendidikan secara umum dan secara khusus prestasi peserta didik. Guru adalah faktor penting kedua penentu hasil belajar peserta didik. Berdasarkan hasil penelitian John Hattie dari 
University of Auckland, terdapat 5 faktor penentu hasil belajar peserta didik yaitu karakteristik peserta didik (49\%), guru (30 \%), lingkungan sekolah, lingkungan keluarga, dan teman sebaya yang masing-masing memiliki pengaruh $7 \%$ (Chang, 2010: 9).

Oleh karena itu untuk mencapai pendidikan yang berkualitas dibutuhkan guru yang berkualitas pula. Rendahnya kualitas pendidikan di Indonesia, tidak terlepas dari masalah rendahnya kualitas guru. Hal ini setidaknya dapat dilihat dari hasil uji kompetensi awal peserta sertifikasi tahun 2012 yang menunjukkan betapa rendahnya kompetensi guru disemua jenjang pendidikan. Sedihnya lagi masih ada guru yang mendapatkan nilai 1 pada rentang nilai maksimum 100 (Kompas, 1 Mei 2012: 13). Hal ini memperkuat pernyataan Mendiknas Muhammad Nuh pada saat itu, bahwa secara nasional kompetensi guru di Indonesia masih rendah.

Guru yang berkualitas dipengaruhi oleh banyak faktor diantaranya adalah kualitas calon guru yang masuk di Lembaga Pendidikan Tenaga Kependidikan (LPTK), proses pendidikan di LPTK, dan manajemen guru yang diterapkan. Manajemen guru yang efektif dimulai dari seleksi yang baik, penempatan yang transparan dan akuntabel, program induksi guru pemula yang efektif, imbalan yang memadai, dan pengembangan karier guru secara berkelanjutan.

\section{B. Metode Kajian}

Metode yang digunakan dalam kajian ini adalah dengen mengetengahkan kondisi manajemen guru secara periodik mulai tahun 1960-an, era orde baru, era reformasi, hingga era otonomi daerah. Selanjutnya digambarkan kondisi manajemen guru yang ideal yang berlaku secara teoretis atau yang berlaku di beberapa negara yang sistem manajemen gurunya telah berjalan dengan baik.

Dengan membandingkan kondisi nyata manajemen guru secara periodik dan kondisi yang ideal tersebut, maka dapat diketahui komponen-komponen apa saja yang perlu diperbaiki. Berdasarkan kesenjangan tersebut maka dapat ditarik kesimpulang dan saran demi perbaikan sistem manajemen guru yang diinginkan.

\section{Pembahasan}

\section{Perkembangan Manajemen Guru Di Indonesia}

Paska kemerdekaan Indonesia hingga tahun 1960-an, jabatan guru sedemikian terpandang. Kondisi ini tidak terlepas dari upaya yang 
dilakukan pemerintah melalui berbagai cara untuk menarik pemuda terbaik menjadi guru. Pada saat itu diantara upaya adalah memberikan ikatan dinas dan asrama bagi pelajar dan mahasiswa calon guru. Tampaknya hal itu merupakan bentuk insentif yang mengundang generasi muda memilih jalur pendidikan untuk menjadi guru. (Tilaar, 2002: 313-314).

Sayang sekali kondisi demikian tidak bisa dipertahankan pada periode selanjutnya. Manajemen guru tidak berjalan dengan efektif yang ditandai dengan tidak adanya pemilihan calon guru secara ketat, proses pendidikan di LPTK yang kurang terkontrol, proses rekrutmen yang tidak transparan dan akuntabel, tidak adanya program induksi bagi guru pemula, hingga penempatan dan pengembangan karier guru tidak terkonsep dengan baik.

Lemahnya manajemen guru menjadikan jabatan guru tidak lagi terhormat di masyarakat. Posisi guru sangat lemah baik secara finansial maupun profesional. Bahkan selama orde baru, para guru mengalami represi dan eksploitasi dari penguasa melalui cara-cara politisasi berbagai kebijakan yang tidak menguntungkan. Akibatnya para guru kurang mendapatkan penghargaan yang wajar dan manusiawi (Rohman, 2009: 193).

Demikian pula pada era reformasi. Pada era ini pelaksanaan sistem pendidikan nasional telah diracuni oleh unsur-unsur korupsi, kolusi, nepotisme, dan kroniisme yang bersifat materiil mapun non materiil untuk memuaskan penguasa. Manajemen guru tidak berjalan dengan baik sehingga profesionalitas guru dikesampingkan dan diganti dengan nepotisme dan kroniisme. Secara umum sistem pendidikan nasional telah terperangkap dalam pekerjaan asal jadi dan asal bapak senang yang akhirnya membuyarkan tujuan pendidikan yang berkualitas (Tilaar, 1999: 18).

Era reformasi ditandai lahirnya Undang-Undang Nomor 22 Tahun 1999 yang diperbaharui melalui Undang-Undang Nomor 32 Tahun 2004 tentang Pemerintahan Daerah. Undang-Undang tersebut disempurnakan kembali melalui Undang-Undang Nomor 12 Tahun 2008. Pendidikan adalah salah satu urusan yang didesentralisasikan kepada daerah otonom dan menjadi tanggung jawab pemerintah daerah provinsi dan kabupaten/kota.

Evaluasi yang dilakukan oleh Bappenas, Depdiknas, dan Bank Dunia pada awal pelaksanaan otonomi daerah menunjukkan bahwa manajemen guru telah diselenggarakan secara desentralistik. Namun terdapat dua indikator menajamen guru yang desentralistik belum 
terwujud yaitu terwujudnya keamanan psikologis guru dalam melaksanakan tugasnya dan mendapatkan jaminan kesejahteaan (Jalal dan Supriyadi, 2001:294). Pada era otonomi ini justru banyak guru yang merasa mendapat tekanan-tenakan dari penguasa lokal.

Berdasarkan Undang-undang tentang Pemerintahan Daerah dan Peraturan Pemerintah Nomor 37 Tahun 2008 tentang Pembagian Urusan antara Pemerintah, Pemerintah Provinsi, dan Pemerintah Kabupaten/Kota manajemen guru menjadi tanggung jawab pemerintah kabupaten/kota. Mulai dari perencanaan kebutuhan, pengangkatan, pemindahan, peningkatan kesejahteraan, pengembangan, dan pemberhentian menjadi tanggung jawab pemerintah kabupaten/kota.

Pada era otonomi daerah inilah justru banyak keluhan muncul dari guru dan masyarakat tentang manajemen guru yang tidak efektif. Mulai dari sistem rekrutmen guru yang tidak transparan dan akuntabel, pengembangan profesionalitas guru yang tidak terjadi, hingga politisasi guru oleh penguasa daerah. Hal-hal tersebut menjadikan guru tidak semakin profesional, sebaliknya semakin terpuruk sehingga upaya-upaya untuk mewujudkan pendidikan berkualitas semakin jauh dari harapan. Oleh karena itu penulis berusaha menukilkan pemikiran untuk mencari alternatif manajemen guru yang efektif mulai dari sistem rekrutmen dan penempatan, indusksi dan jaminan kesejahteraan, serta pengembangan keprofesionalan guru.

Sejak jaman Plato, pendidikan erat kaitannya dengan politik. Dalam bukunya Republik, Plato menyatakan bahwa tujuan pendidikan tidak bisa dipisahkan dari tujuan negara karena tujuan pendidikan identik dengan tujuan negara yang tidak lain adalah tujuan hidup manusia. Tujuan negara secara umum adalah membangun masyarakat yang sejahtera dan berkeadilan. Masalah pendidikan adalah masalah politik, karena suatu masalah akan masuk ke ranah politik apabila pemerintah wajib untuk menanganinya (Kartono, 1997: 26-27).

Di Indonesia, pendidikan adalah jelas urusan politik karena di dalam UUD 1945 pasal 31 ayat 3 dinyatakan bahwa pemerintah mengusahakan dan menyelenggarakan satu sistem pendidikan nasional, yang meningkatkan keimanan dan ketakwaan serta akhlak mulia dalam rangka mencerdaskan kehidupan bangsa yang diatur dengan undangundang. Namun kaitan pendidikan dan politik akhir-akhir ini telah salah arah. Pendidikan telah dipolitisasi oleh penguasa. Isu-isu pendidikan seperti beasiswa dan bantuan pendidikan lainnya telah menjadi isu politik untuk meraih dukungan suara bagi calon eksekutif maupun legislatif. 
Pada jaman penjajahan, pendidikan dijadikan alat bagi penguasa untuk meredam keinginan-keinginan bangsa yang dijajah. Namun gerakan pendidikan pula yang telah mendorong negara-negara terjajah untuk merdeka. Kini setelah jauh dari merdeka, pendidikan dijadikan alat oleh para penguasa untuk melanggengkan kekuasannya. Padahal praktik pendidikan yang dilaksanakan berdasarkan kekuasaan akan menimbulkan empat masalah besar yaitu: (a) membunuh kreativitas dan pembodohan masyarakat, (b) terjadinya indoktrinasi, (c) ancaman terhadap demokrasi, dan (d) ancaman integrasi sosial (Tilaar, 2009: 146).

Beberapa tahun terakhir ini praktik politisasi pendidikan semakin parah dan kasar dirasakan para guru. Banyak guru yang dimutasi ke daerah-daerah pinggiran karena tidak mendukung kepala daerah terpilih. Banyak guru dan profesional pendidikan dipindah ke satuan kerja perangkat daerah (SKPD) non pendidikan karena tidak menjadi tim sukses kepala daerah terpilih.

Politisasi guru dan tenaga kependidikan yang demikian parah ini harus mendapat perhatian dari otoritas pendidikan agar tidak berlarutlarut. Oleh karena itu harus segara dilakukan peninjauan terhadap Peraturan Pemerintah Nomor 37 Tahun 2008 tentang Pembagian Urusan antara Pemerintah, Pemerintah Provinsi dan Pemerintah Kabupaten/Kota.

\section{Manajemen Guru Yang Efektif}

Manajemen guru yang efektif dimulai sejak perkrutan, penempatan, induksi guru baru, kesejahteraan yang baik, dan pengembangan keprofesionalan berkelanjutan. Berikut adalah beberapa langkah yang dapat dilakukan dalam melakukan manajemen guru yang efektif.

a. Sistem Rekruitmen dan Penempatan Guru

Di negara-negara dengan sistem pendidikan terbaik di dunia memiliki sistem seleksi calon guru yang sangat ketat sejak penjaringan calon mahasiswa. Hal ini disadari karena sistem seleksi yang buruk akan menghasilkan kualitas guru yang buruk selama 40 tahun ke depan. Guru yang kualitasnya buruk akan menjadi racun dalam sistem pembelajaran dan merusak masa depan ribuan bahkan jutaan peserta didik selama guru tersebut bertugas.

Guru-guru di Indonesia mayoritas bukan dari lulusan terbaik sekolah menengah atas. Padalah menurut James B. Conant idealnya mereka yang menjadi guru berasal dari kelompok $20 \%$ terbaik lulusan sekolah menengah atas. Hal ini telah diterapkan di University of California yang mensyaratkan mahasiswa yang masuk 
jurusan keguruan harus berasal dari $10 \%$ kelompok teratas lulusan sekolah menengah, juga di State University of California disyaratkan $20 \%$ teratas lulusan sekolah menengah (Tilaar, 2002: 314).

Di Singapura calon guru harus berasal dari $30 \%$ lulusan terbaik dan di Findlandia calon guru dijaring dari mereka yang termasuk 20 $\%$ lulusan terbaik pula. Di dua negara tersebut sangat menekankan pentingnya kompetensi akademik, keterampilan komunikasi, dan motivasi untuk menjadi guru (Barber and Mourshed, 2007:17).

Pengalaman negara-negara yang tergabung dalam OECD yang memiliki sistem pendidikan terbaik di dunia menunjukkan bahwa terdapat tiga hal yang sangat berpengaruh terhadap kualitas pendidikan. OECD adalah Organization for Economic Cooperation and Development yang beranggotakan 30 negara untuk kerjasama antara lain pengembangan ekonomi dan sosial. Ketiga hal tersebut adalah: (a) mendapatkan orang yang tepat untuk menjadi guru melalui sistem seleksi yang efektif, (b) proses pembelajaran di LPTK yang efektif dengan para pengajar yang berkulitas, dan (c) memastikan bahwa sistem yang ada mampu meberikan kemungkinan pembelajaran terbaik untuk setiap peserta didik (Barber and Mourshed, 2007:2).

Kesimpulan tersebut diambil berdasarkan hasil penelitian tahun 2006/2007 terhadap 25 negara OECD dengan sistem pendidikan terbaik. Akhirnya terpilih sepuluh negara yang memiliki skor PISA (Programme for International Student Assessment) atau TIMSS (Trends in International Mathematics and Science Studies) terbaik pada tahun 2003 dan menjadi benchmark negara-negara pendidikan berkualitas. Kesepuluh negara tersebut adalah Kanada, Australia, Belgia, Finlandia, Hongkong, Jepang, Belanda, New Zealand, Singapura, dan Korea Selatan. Kesepuluh negara tersebut oleh McKensey juga dianggap mengalami sukses basar dalam mereformasi sistem pendidikannya.

Salah satu bab dalam laporan penelitian tersebut tertulis secara mengejutkan "the quality of an education system cannot exceed the quality of the teacher". Jelas sekali bahwa guru menempati posisi penting di negara-negara maju tersebut untuk meningkatkan kualitas pendidikan. Oleh karena itu negara-negara dengan sistem pendidikan terbaik secara konsisten mencari caloncalon guru terbaik untuk menekuni profesi guru.

Guru-guru yang baik akan melahirkan prestasi peserta didik yang baik pula. Untuk menarik calon guru terbaik dilakukan dengan 
proses seleksi secara ketat dan memberikan gaji yang baik terhadap guru pemula. Dengan cara ini maka status profesi guru menjadi semakin meningkat sehingga dapat menarik putra-putri sebaik untuk menjadi guru.

Disebutkan dalam laporan McKinsey \& Co, terdapat bukti yang menunjukkan bahwa faktor utama variasi hasil belajar peserta didik di sekolah adalah kualitas guru. Penelitian yang dilakukan di Tennessee menunukkan bahwa terdapat dua rerata peserta didik usia 8 tahun yang diajar oleh guru yang berbeda yaitu satu guru memiliki kualitas tinggi dan satunya berkualitas rendah, maka dalam waktu 3 tahun hasil belajar peserta didik memiliki perbedaan 53 poin persentil (Barber and Mourshed, 2007:12).

Dari paparan di atas jelas terbaca bahwa mencari calon guru yang berkualitas adalah syarat penting untuk menciptakan pendidikan yang berkualitas. Oleh karena itu dalam proses seleksi guru, kompetensi calon guru harus menjadi pertimbangan utama. Proses seleksi harus dijauhkan dari unsur-unsur korupsi, kolusi, dan nepotisme yang selama ini menjadi kritik masyarakat.

Menteri Pendidikan dan Kebudayaan Muhammad Nuh mengemukakan bahwa mulai tahun 2012 sistem rekturmen calon guru akan diperbaharui. Seseorang yang dinyatakan lulus masuk LPTK akan disaring kembali dengan mempertimbangkan empat kompetensi yaitu profesional, paedagogi, kepribadian, dan sosial. Setelah lulus uji empat kompetensi tersebut langsung diasramakan selama empat tahun. Para calon guru akan diberi beasiswa dan ikatan dinas. Setelah lulus dari LPTK mendapat sertifikat pendidik yang dijadikan syarat perekrutan calon guru (Kedaulatan Rakyat: 25 April 2012: 15). Formula baru ini tampaknya akan mampu menarik calon dari lulusan sekolah menengah terbaik untuk menjadi guru.

Biaya pendidikan calon guru akan ditanggung oleh pemerintah hingga lulus. "Nantinya tidak sembarang orang bisa mejadi guru, hanya orang yang terpilih yang kelak bisa mendidik anak-anak bangsa", kata Direktur Pendidik dan Tenaga Kependidikan Dirjen Dikti Kemdikbud, Supriadi Rustad (Kompas, 1 Juni 2012)

Salah satu masalah terkait manajemen guru di Indonesia adalah pemerataan guru. Saat ini guru terkonsentrasi di daerah perkotaan sehingga daerah pinggiran mengalami kekerungan. Kondisi ini diperparah karena banyak guru yang semula ditugaskan di daerah pinggiran beramai-ramai minta pindah ke perkotaan. 
Guru yang dalam pendidikan dan rekrutmen dilakukan dengan kualitas baik, tidak akan dapat menghasilkan kualitas pendidikan yang tinggi apabila pola penempatan dan pembinaanya tidak dilaksanakan secara adil dan proporsional yang diikuti dengan proses pembinaan yang terus menerus. (Tilaar, 2002: 317-318). Perlakuan khusus terhadap guru yang ditugaskan di daerah terpencil harus terus mendapat perhatian baik keamanan maupun kesejahteraannya.

Oleh karena itu sistem seleksi dan penempatan guru harus transparan dan akuntabel serta dijauhkan dari praktik-praktik kolusi dan nepotisme. Aturan harus ditegakkan dengan penuh kebijaksanaan dan keadilan sehingga tidak merugikan masyarakat luas. Berbagai surat sakti dari eksekutif maupun legislatif atau orang kuat lainnya harus dihindarkan. Dengan cara ini maka tingkat kepercayaan masyarakat terhadap pemerintah akan semakin baik, sehingga partisipasi masyarakat dalam membangun pendidikan yang berkualitas juga semakin baik.

b. Induksi dan Jaminan Kesejahteraan

Pepatah mengatakan bahwa pengalaman adalah guru yang utama, oleh karena itu guru pemula perlu memahami isi pepatah tersebut. Guru pemula harus mencari pengalaman terlebih dahulu sebelum menjadi guru profesional melalui program induksi.

Banyak ahli berpendapat bahwa sepandai apapun seorang calon guru, tidak dapat diterjunkan langsung menjadi guru yang otonom. Lingkungan sekolah memiliki budaya dan iklim kerja yang berbeda ketika calon guru masih menjadi mahasiswa. Oleh karena itu guru pemula harus dapat menyesuaikan diri dalam lingkungan kerja di sekolah baik kepada peserta didik, guru, tenaga administrasi, dan lingkungan psikologis lainnya.

Permendiknas Nomor 27 Tahun 2010 menyatakan "program induksi adalah kegiatan orientasi, pelatihan di tempat kerja, pengembangan, dan praktik pemecahan berbagai permasalahan dalam proses pembelajaran/bimbingan dan konseling bagi guru pemula pada sekolah/madrasah di tempat tugasnya".

Program ini bertujuan untuk membimbing guru pemula agar dapat: (a) beradaptasi dengan iklim kerja dan budaya sekolah/madrasah, dan (b) melaksanakan pekerjaannya sebagai guru profesional di sekolah/madrasah. Seharusnya program ini dimulai awal tahun 2012 ini namun hingga saat ini belum berjalan dengan baik. 
Di banyak negara program induksi telah dilaksanakan sejak lama dengan jangka waktu lebih panjang, misalnya di Amerika Serikat dan Selandia Baru. Di Amerika Serikat program induksi dilaksanakan selama 3 tahun.

Beberapa hasil penelitian menunjukkan bahwa program induski berdampak positif terhadap peningkatan profesionalitas guru pemula. Hubungan yang intensif antara guru pemula dengan guru senior sebagai mentor dapat meningkatkan kualitas pembelajaran. Peningkatan kualitas pembelajaran ini terjadi karena guru pemula berajar melalui praktik terbimbing dan bukan sekedar coba-coba (Danim, 2011: 63).

Calon guru yang berkualitas, penempatan guru yang transparan dan akuntabel, dilengkapi dengan program indusksi yang efektik akan mempersiapkan guru yang profesional. Namun profesionalitas guru sulit terwujud bila imbalannya kurang memadai. Sebagai profesi guru harus mendapatkan imbalan yang baik. Oleh karena itu jaminan kesejahteraan guru pada era ini merupakan suatu keniscayaan.

Jaminan kesejahteraan guru adalah sebagai salah satu penentu kinerja guru yang profesional dan bertanggungjawab. Penghasilan guru minimal harus dapat memenuhi rasa aman untuk memenuhi kebutuhan pengobatan, tempat tinggal, transportasi, dan makan yang bergizi. Artinya gaji dan tunjangan guru harus cukup untuk memenuhi kebutuhan guru minimal tersebut (Tilaar, 2002: 319320).

Kesejahteraan adalah salah satu variabel penting dalam setiap profesi termasuk profesi guru. Profesionalitas guru ditentukan oleh beberapa komponen yaitu: ilmu pengetahuan yang dimilikinya 20 $\%$, keterampilan $25 \%$, insentif $60 \%$, dan dedikasi $5 \%$. Semakin besar insentif maka semakin tinggi dedikasi terhadap profesi. Salah satu kriteria yang menentukan ketertarikan seseorang pada suatu profesi akan ditentukan oleh besarnya insentif baik materiil maupun non materiil, berupa gaji, tunjangan, dan insentif lainnya (Tilaar, 1999: 329-330).

Gaji guru di Indonesia secara berangsur-angsur mengalami peningkatan. Sampai dengan tahun 2002 rata-rata gaji guru pegawai negeri masih berada di bawah gaji pegawai negeri nonguru, pada tahun 2010 telah berada di atas rata-rata gaji pegawai negeri non-guru bagi guru yang berusia 40 tahun ke atas. Hal ini tidak terlepas dari program pemerintah yang memberikan 
tunjangan profesi kepada para guru yang telah lulus sertifikasi. Bahkan mulai tahun 2014 gaji guru pegawai negeri untuk segala tingkat usia sudah berada di atas rata-raga gaji pegawai negeri nonguru (Chang, 2010: 18-20).

Bila dibandingkan dengan negara maju seperti Amerika Serikat (AS) dan neraga-negara yang tergabung dalam OECD, gaji guru di Indonesia memang masih rendah. Pada tahun 2007 rata-rata gaji guru SDN di AS yang telah mengajar selama 15 tahun mencapai 43.633 dolar AS, sementara di OECD rata-rata mencapai 39.007 dolar AS (Rampell, 2009). Bila pada tahun itu dengan pengalaman kerja yang sama gaji guru SDN di Indonesia mencapai Rp. 3 juta per bulan dengan kurs Rp. 9.000 per dolar maka setara dengan 4.000 dollar AS. Artinya gaji guru SDN di Indonesia 11 kali lebih kecil dibanding gaji guru di AS atau 10 kali lebih kecil dari rata-rata gaji guru SDN di negara-negara OECD.

Gaji yang besar di AS dan negara-negara OECD tersebut sepadan dengan tugas jam mengajar per minggu untuk setiap guru. Di Indonesia sesuai dengan Peraturan Pemerintah Nomor 74 Tahun 2008 bahwa beban mengajar seorang guru adalah minimal 24 jam perminggu. Namun kenyataannya tidak semua guru bisa mengajar sesesui dengan ketentuan tersebut. Padahal di AS setiap guru mengajar 30 jam per minggu

Dengan berbagai langkah tersebut penulis merasa optimis bisa mencetak guru yang profesional. Namun profesionalitas guru harus terus diasah seiring perkembangan ipteks. Oleh karena itu pengembangan profesionalitas guru berkelanjutan sudah menjadi tuntutan setiap guru.

c. Pengembangan Keprofesionalan Guru

Rekrutmen guru yang efektik dilanjutkan dengan penempatan guru yang sistematis, adil, proporsional, dan imbalan yang baik perlu ditunjang dengan sistem pembinaan keprofesionalan yang terus menerus. Bolam mengemukakan bahwa pengembangan profesional berkelanjutan atalah proses berkelanjutan dalam pendidikan, pelatihan, dan pembelajaran baik di dalam pekerjaan atau di luar pekerjaan yang bertujuan terutama untuk meningkatkan dan mengembangkan pengetahuan, keterampilan dan nilai-nilai profesional (Bush and Bell, 2002: 103).

Di Indonesia pengembangan keprofesional perkelanjutan guru sesuai dengan Peraturan Menteri Pendayagunaan Aparatur Negara dan Reformasi Birokrasi Nomor 16 Tahun 2009. Disebutkan 
"pengembangan keprofesian berkelanjutan adalah pengembangan kompetensi guru yang dilaksanakan sesuai dengan kebutuhan, bertahap, berkelanjutan untuk meningkatkan profesionalitasnya."

Kenyataannya pengembangan keprofosionalan guru semakin terabaikan di era otonomi daerah ini karena anggaran pendidikan tidak dialokasikan oleh pemerintah kabupaten/kota untuk keperluan tersebut. Anggaran pemerintah kabupaten/kota sebagian besar telah dihabiskan untuk belanja gaji pegawai sehingga tidak memungkinkan untuk mengembangkan profesionalitas guru.

Menurut Forum Indonesia untuk Transparansi Anggaran (Fitra), pada tahun 2012 terdapat 291 kabupaten/kota yang memproyeksikan belanja pegawainya lebih dari $50 \%$. Di Indonesia saat ini terdapat 398 kabupaten dan 93 kota. Diantara 291 daerah itu, 11 daerah yang memilik belanja pegawai lebih dari $70 \%$ dari APBD. Daerah-daerah ini terancam bangkrut. Kepala Divisi Pengembangan Jaringan Fitra, Hadi Prayitno mengatakan bahwa sisa anggaran untuk belanja program kegiatan hanya 9 \%-14 \%. Padahal idealnya alokasi belanja aparatur adalah $40 \%$ dari belanja daerah (Jawa Pos, 10 April 2012: 1).

Kesebelas daerah tersebut adalah Kota Langsa (NAD), Kabupaten Kuningan (Jabar), Kota Ambon (Maluku), Kabupaten Ngawi (Jatim), Kabupaten Bantul (DIY), Kabupaten Bireuen (NAD), Kabupaten Klaten (Jateng), Kabupaten Aceh Barat (NAD), Kabupaten Gorontalo (Gorontalo), Kabupaten Karanganyar (Jateng), dan Kabupaten Padang Sidempuan (Sumut).

Menghadapi masalah ini Dirjen Otonomi Daerah Djoehermansyah Johan mengatakan bahwa akan ada reviuw terhadap daerah-daerah otonom, bila tidak bisa ditolong terancam dilikuidasi dengan daerah terdekat atau pusat. (Jawa Pos, 11 April 2012: 1 \& 15).

Terdapat empat strategi pengembangan profesional guru yang banyak diterapkan di banyak negara maju (Bush and Bell, 2002: 108). Pertama, menetapkan standar nasional profesional guru (standard of professional practice). Di Indonesia menerapan standar ini tertuang dalam Undang-Undang Nomor 20 Tahun 2003 tentang Sistem Pendidikan Nasional dan Undang-Undang Nomor 14 tahun 2005 Tentang Guru dan Dosen. Dalam dua undang-undang tersebut ditetapkan bahwa standar guru yang profesional adalah memenuhi kualifikasi akademik S1/DIV dan tersertifikasi. Guru yang 
tersertifikasi harus memiliki kompetensi profesional, paedagogik, sosial, dan kepribadian.

Kedua, membiasakan para guru dengan hasil-hasil penelitian terbaru (efidence informed practice) dan membiasakan guru melakukan penelitian. Di Indonesia praktik ini belum biasa, guru masih sulit untuk melakukan penelitian dan menggunakan hasilhasil penelitian dalam proses pembelajaran. Guru belum banyak yang menggunakan sebagian tunjangan profesinya untuk membiayai penelitian dalam rangka pengembangan profesi.

Cara lain untuk mengembangkan profesional adalah berlangganan jurnal-jurnal ilmiah, membacanya, menulis di jurnal, mengikuti seminar dan lokakarya (Heck dan Williams, 1984: 12-13). Itulah kebiasaan guru-guru di negara maju yang menggunakan sebagaian tunjangannya untuk mengembangkan profesionalitasnya. Guru-guru kita perlu meniru dan memulai kegiatan ini, dengan menyisihkan sebagaian tunjangan profesinya untuk membeli laptop, berlangganan internet, berlangganan jurnal ilmiah, melakukan penelitian, dan menulis di jurnal ilmiah. Karena tunjangan profesi pada hakikatnya selain untuk meningkatkan tingkat kesejahteraan guru juga untuk meningkatkan profesionalitasnya.

Ketiga, manajemen kinerja dan penggajian berdasarkan kinerja (performance management and performance-related pay). Di Inggris setiap tahun dilakukan penilaian terhadap kinerja guru yang dijadikan dasar untuk menentukan gaji guru tahun berikutnya. Di Indonesia praktik penilaian kinerja guru sudah dilakukan melalui DP3, namun gaji guru tidak pernah didasarkan pada penilaian kinerja tersebut. Faktanya DP3 tidak boleh mengalami penurunan dari tahun sebelumnya, walaupun kinerja guru tidak lebih baik dari tahun ke tahun.

Program Penilaian Kinerja Guru (PKG) harus segera diimplementasikan dalam rangka menilai kinerja guru secara obyektif. Dengan PKG ini guru akan dinilai kemampuannya dalam menerapkan semua kompetensi dan keterampilan pembelajaran, pembimbingan, dan pelaksanaan tugas tambahan.

Keempat, menjadi masyarakat profesional pembelajar (professional learning communities). Guru yang menjadi masyarakat pembelajar adalah yang berkolaborasi dengan guru profesional lainnya baik di dalam sekolah maupun di luar sekolah dan memiliki akses kepada guru-guru yang ahli. Hal ini dilakukan melalui 
organisasi profesi, guru mata pelajaran sejenis melalui media seminar, lokakarya, pelatihan dan lain sebagainya. Di Indonesia akhir-akhir ini kegiatan semacam ini sangat laris, tapi tujuannya bukan untuk meningkatkan kompetensi tetapi hanya untuk mendapatkan sertifikat untuk melengkapi portofolio. Maka banyak sekali pelatihan aspal yang memberikan sertifikat asli tetapi kegiatannya tidak ada, atau ada kegiatannya tapi orangnya tidak ada namun tetap mendapatkan sertifikat.

Salah satu bentuk pengembangan profesi guru adalah melalui program penataran. Kelemahan penataran yang dilaksanakan selama ini adalah bersifat masal dan kurang didasarkan pada analisis kebutuhan. Akibatnya penataran yang dilaksanakan tidak efisien dan tidak efektif (Tilaar, 2002: 318-319).

Di Indonesia, hanya sekitar $5 \%$ guru yang berpelung mengikuti pengembangan profesi secara terlembaga dalam bentuk penataran atau pelatihan. Berarti setiap guru berpeluang mengikuti pengembangan profesi sebanyak satu kali dalam 20 tahun, jika kesempatan diberikan secara merata. Kenyataannya kesempatan pengembangan profesi tersebut tidak selalu merata kepada setiap guru (Danim, 2011:8).

Kelemahan penataran yang selama ini diterapkan adalah, selesai penataran guru tidak bisa menerapkan pada proses pembelajaran di kelas. Pada waktu ditatar, guru banyak yang menunjukkan prestasi yang baik, tapi setelah kembali ke sekolah mereka kembali kepada praktik pembelajaran lama. Hal itu terjadi karena penataran yang diterapkan selama ini menggunakan pendekatan top down sehingga para guru kurang memiliki komitmen. Guru tidak pernah ditanya mengenai kebutuhan terkait proses peningkatan profesionalitasnya (Suyanto dan Hisyam, 2000: 30-31).

Seharusnya kegiatan-kegiatan untuk mengembangkan keprofesionalan guru didasarkan pada kebutuhan melalui proses identifikasi kebutuhan. Bisa berdasarkan kebutuhan individu seperti pengembangan pribadi, profesional, dan karier; kebutuhan kelembagaan atau kelompok seperti pengembangan kurikulum, keorganisasian, dan manajemen; atau kebutuhan nasional seperti pengembangan kurikulum, evalulasi, dan pendanaan (Oldroyd dan Hall dalam Kydd, Crawford, and Riches. 1997: 135). Jika jenis pelatihan telah ditetapkan dan dilaksanakan, maka perlu dilakukan monitoring dan evaluasi. Terkait dua kegiatan terakhir ini, kita 
masih jarang melakukannya apalagi sampai mengukur dampak dari pelatihan terhadap kinerja guru.

Pengembangan profesional berkelanjutan adalah bagian penting pagi guru. Hal ini tidak terjadi begitu saja, melainkan harus direncanakan dan diupayakan melalui perbagai kesempatan. Salah satu cara yang ditempuh guru adalah menjadi anggota organisasi profesi dan menghadiri pertemuan-pertemuan profesional yang agendanya biasanya merefleksikan kebutuhan dan ketertarikan guru (Heck dan Williams, 1984: 10). Di negara-negara maju, menjadi anggota organisasi profesi dan menghadiri pertemuan-pertemuan profesional adalah bertujuan untuk mengembangkan kapasitas profesional, namun di negeri ini keikutsertaan kita hanya sekedar untuk mendapatkan pengakuan yang berupa sertifikat untuk kepentingan administratif.

Guru yang menjadi masyarakat profesional pembelajar inilah yang disebut sebagai guru madani yang oleh Danim disebut sebagai "the civil teachers are beyond the professional teachers" yaitu guru madani melebihi batas-batas guru profesional. Guru semacam itu akan mampu mengembangkan diri sendiri tanpa tergantung pada skema pengembangan profesi yang disusun oleh lembaga sekolah, pemerintah daerah, atau pemerintah pusat. Bila guru telah membentuk masyarakat profesional pembelar maka akan terwujudlah professional civil teacher atau guru profesional madani (GPM).

\section{Kesimpulan}

Desentralisasi dalam kewenangan akan diikuti dengan desentralisasi keuangan, bila hal ini tidak terjadi maka tujuan desentralisasi yaitu untuk memberikan pelayanan yang lebih baik kepada masyarakat tidak akan tercapai. Oleh karena itu kemampuan keuangan pemerintah kabupaten/kota harus ditingkatkan dengan revesisi Undang-Undang Nomor 28 Tahun 2009 tentang Pajak dan Retribusi. Pembagian pajak dan retribusi untuk pemerintah kabupaten/kota harus perbesar. Demikian pula Undang-Undang Nomor 33 Tahun 2004 tentang Perimbangan Keuangan antara Pemerintah Pusat dan Pemerintah Daerah perlu diperbaiki.

Peraturan Pemerintah Nomor 37 Tahun 2007 juga perlu direvisi dengan lebih memperjelas peran pemerintah, pemerintah provisi, dan pemerintah kabupaten/kota dalam bidang pendidikan. Disarankan, peran pemerintah adalah menetapkan kriteria calon guru dari segi 
akademik dan kepribagian, menetapkan jumlah kebutuhan guru yang harus dididik dalam jangka pendek dan jangka panjang, menentukan kuota kepada masing-masing LPTK untuk mendidik calon guru, dan menetapkan standar gaji guru yang baru.

Peran pemerintah provinsi adalah melakukan rekrutmen dan seleksi guru berdasarkan kompetensi akademik, paedagogik, kepribadian dan sosial; penempatan, pengangkatan dan mutasi guru; pembinaan dan pengembangan profesionalitas guru jenjang pendidikan menengah baik umum maupun kejuruan, membayar gaji dan tunjangan guru mulai dari jenjang anak usia dini, dasar, dan menengah.

Peran pemetintah kabupaten/kota adalah melakukan evaluasi kinerja guru yang secara teknis dilakukan oleh kepala sekolah dan pengawas, pembinaan dan pengembangan profesionalitas guru jenjang pendidikan anak usia dini dan pendidikan dasar, memberikan tunjangan kesejahteraan tambahan guru. Tunjangan kesejahteraan guru didasarkan pada hasil evaluasi kinerja guru pada tahun sebelumnya.

Sistem rekrutmen dan penempatan guru harus diperbaiki sehingga lebih transpran dan akuntabel. Untuk itu perlu partisipasi dari berbagai pihak dalam memantau pelaksanaan rekrutmen dan penempatan guru. Induksi guru pemula harus segera diterapkan untuk seluruh guru baru. Kehidupan yang sejahtera adalah dambaan semua guru dan harus diwujudkan dengan didasarkan pada penilaian kinerja guru yang obyektif.

Pengembangan profesionalitas guru harus diprogramkan secara serius baik oleh pemerintah pusat, provinsi, dan kabupaten/kota sehingga dapat menjamin pendidikan yang berkualitas. Dengan demikian guru yang profesional dapat diwujudkan dan akirnya dapat melahirkan pendidikan yang berkualitas.

\section{E. Daftar Rujukan}

Barber, M dan Mourshed, M. 2007. How The World's Best-Performing School Systems Come Out On Top. No city: McKinsey \& Company.

Buss, T and Bell, L. (editors). 2002. The Principles and Practice of Educational Management. London: Paul Chapman Publishing.

Chang, M.C. 2010. Supporting Teacher Reform in Indonesia (Presentasi). Jakarta: Kongres Guru Indonesia 2010.

Danim, S. 2011. Pengembangan Profesi Guru: Dari Prajabatan, Induksi, Ke Profesional Madani. Jakarta: Kencana.

Heck, S.F dan Williams C.R. 1984. The Complex Roles of Teacher: An Ecological Perspective. New York: Teacher College Press. 
Jalal, F. Dan Supriyadi D. 2001. Reformasi Pendidikan Dalam Konteks Otonomi Daerah. Yogyakarta: Adicita.

Jawa Pos. 10 April 2012. Sebelas Daerah Terancam Kolaps. Jawa Pos. 11 April 2012. Daerah Bangkrut Dilikuidasi.

Kartono, K. 1997. Tinjauan Politik Sistem Pendidikan Nasional: Beberapa Kritik dan Solusi. Jakarta: PT. Pradnya Paramita.

Kedaulatan Rakyat, 25 April 2012. Sistem Rekrutment Guru Diperharui. Kompas. 1 Mei 2012. Peningkatan Kualitas Guru Butuh Jawaban. Kompas. 1 Juni 2012. Kuota LPTK Dibatasi.

Kydd, L.; Crawford,M.; Riches, C (editors). 1997. Professional Development for Educational Management. Buckingham: Open University Press.

Peraturan Menteri Pendayagunaan Aparatur Negara dan Reformasi Birokrasi Nomor 16 Tahun 2009 tentang Jabatan Fungsional Guru dan Angka Kreditnya.

Peraturan Menteri Pendidikan Nasional Nomor 27 Tahun 2010 tentang Program Induksi Bagi Guru Pemula.

Peraturan Pemerintah Nomor 37 Tahun 2008 tentang Pembagian Urusan Antara Pemerintah, Pemerintah Provinsi dan Pemerintah Kabupaten/Kota.

Peraturan Pemerintah RI Nomor 74 tahun 2008 tentang Guru.

Rampell, C. 2009. Teacher Pay Arround The Word. Internet.

Rohman, A. 2009. Politik Ideologi Pendidikan. Yogyakarta: Laksbang Mediatama Yogyakarta.

Suyanto dan Hisyam, D. 2000. Refleksi dan Reformasi Pendidikan Di Indonesia Memasuki Milenium III. Yogyakarta: Adicita Karya Nusa.

Tilaar, H.A.R. 1999. Beberapa Agenda Reformasi Pendidikan Nasional Dalam Perspektif Abad 21. Magelang: Indonesia Tera.

Tilaar, H.A.R. 2002. Soedijarto. Rekrutmen, Pendidikan, dan Penempatan, serta Pembinaan Guru untuk Menunjang Pendidikan yang Relevan dan Bermudu. Pendidikan Untuk Masyarakat Indonesia Baru: 70 Tahun Prof. Dr. H.A.R. Tilaar, MSc.Ed. Jakarta: Grasindo.

Tilaar, H.A.R. 2009. Kekuasaan dan Pendidikan: Manajemen Pendidikan Nasional Dalam Pusaran Kekuasaan. Jakarta: Rineka Cipta. Undang-Undang Dasar Negara Republik Indonesia Tahun 1945. Undang-Undang Nomor 14 Tahun 2005 tentang Guru dan Dosen. Undang-Undang Nomor 20 Tahun 2003 tentang Sistem Pendidikan Nasional. 